\title{
ZERO FOOD WASTE: PASAR HIJAU TRADISIONAL DI GROGOL, JAKARTA BARAT
}

\author{
Felia Alexandra Linoh ${ }^{1)}$, Denny Husin ${ }^{21}$
}

1)Program Studi S1 Arsitektur, Fakultas Teknik, Universitas Tarumanagara, felia.alexandra@gmail.com

2) Program Studi S1 Arsitektur, Fakultas Teknik, Universitas Tarumanagara, denny@ft.untar.ac.id

\begin{abstract}
Abstrak
Fenomena sampah makanan adalah salah satu isu ekologi yang merugikan di kota kota besar seperti Jakarta. Sampah makanan yang menumpuk di TPA (tempat pembungan akhir) dapat menghasilkan gas metana yang dapat merusak lapisan ozon. Masalahnya, pengelolaan sampah makanan di Indonesia masih buruk, nyatanya Indonesia adalah negara ke-2 penyumbang sampah makanan terbesar. Sampah kota di Indonesia rata-rata masih mengandung 55 sampai $60 \%$ bahan organik. Salah satu sektor penyumbang terbesar sampah makanan adalah sektor pangan seperti pasar. Untuk menangani isu sampah makanan dalam sektor tersebut, diperlukan suatu sistem dalam arsitektur berupa siklus dalam satu bangunan yang tertutup. Oleh karena itu, proyek ini berusaha menerapkan metode siklus penanganan sampah makanan yang tertutup dengan menambahkan program-program lain yang relevan ke dalam pasar tradisional sehingga dapat mencapai arsitektur hijau dengan zero food waste.
\end{abstract}

Kata kunci: arsitektur; hijau; sistem.

\begin{abstract}
Food waste is one of the ecological issues that have a detrimental effect on big cities like Jakarta. Food waste that decomposes in landfills releases methane that can be harmful to ozone layers. The problem is that Indonesia's food waste management is poorly handled; in fact, Indonesia is the world's second-largest food waster. Indonesian cities waste contains approximately 55-60\% organic matter. One of the biggest sectors that generate food waste is food retailers such as the marketplace. The solution for handling the food waste issues in this sector is to create a closed cycle food waste in architecture system within a building. Therefore, this project attempts to apply a closed-cycle food waste method by adding another relevant program into the marketplace to achieve green architecture with zero food waste.
\end{abstract}

Keywords: architecture; green; system.

\section{PENDAHULUAN \\ Latar Belakang}

Sampah makanan adalah salah satu permasalahan ekologi yang terdapat pada kota-kota besar seperti di Jakarta. Sampah makanan yang menumpuk pada Tempat Pembuangan Akhir (TPA) dapat meghasilkan gas metana yang dapat merusak lapisan ozon (Dewi, 2020). FAO menyatakan bahwa sekitar 33\% hingga 50\% makanan yang telah diproduksi, tidak dikonsumsi dengan semestinya. Ada beberapa hal yang menyebabkan makanan tidak dapat dikonsumsi antara lain makanan dapat rusak pada proses panen dan distribusi, maupun konsumsi. Sampah makanan yang terjadi pada level konsumen atau distributor dapat disebabkan karena produk makanan tidak memenuhi standard supermarket berdasarkan berat, ukuran, maupun penampilan (Stuart, 2009). Proses tersebut terjadi pada sektor yang berhubungan dengan pangan seperti pada pasar tradisional. Sistem distribusi pangan ke kota kota besar menjadi salah satu penyebab terjadinya sampah makanan karena penanganan yang buruk terhadap bahan pangan seperti minimnya 
tempat penyimpanan bahan pangan yang baik sebelum sampai ke konsumen. Sampah makanan harus diolah supaya tidak berdampak buruk ke lingkungan.

\section{Rumusan Permasalahan}

Sektor pangan seperti pasar maupun restoran merupakan penyumbang sampah makanan terbesar di Jakarta. Sampah kota di Indonesia rata-rata mengandung 55 sampai $60 \%$ bahan organik. Menurut data Sistem Informasi Pengelolaan Sampah Nasional KLHK tahun 2017-2018, komposisi sampah sisa makanan di Jakarta barat merupakan yang tertinggi diantara daerah metropolitan lainnya dengan $70 \%$ komposisi dari sampah adalah sampah makanan.

Oleh karena itu perlu wadah untuk menangani permasalahan sampah makanan pada sektor tersebut di Kota Jakarta. Proyek ini menerapkan suatu sistem arsitektur yang mengolah sampah makanan dimana sampah makanan dalam pasar dimanfaatkan kembali dan di daur ulang dengan cara menerapkan program program arsitektur dalam pasar.

\section{Tujuan}

Berdasarkan latar belakang dan identifikasi masalah, tujuan dari proyek ini adalah membuat suatu sistem terapan dalam pasar tradisional dengan memanfaatkan sampah makanan sebagai obyek yang penting dalam membentuk sistem daur yang tertutup untuk menghasilakan zero food waste.

\section{KAJIAN LITERATUR}

\section{Sampah Makanan}

Definisi sampah makanan oleh FAO berarti jumlah sampah yang dihasilkan pada saat proses pembuatan makanan maupun setelah kegiatan makan yang berhubungan dengan perilaku penjual dan konsumennya. Masalah limbah pangan (food waste) secara global menjadi perhatian khusus untuk diatasi baik dalam mengurangi kelaparan maupun dalam meningkatkan kelestarian lingkungan dengan mengurangi emisi karbon dan penggunaan landfill (Finn, 2011). Sampah kota di Indonesia rata-rata masih mengandung 55-60\% bahan organik. Di TPA sampah kota masih dipilah secara manual oleh pemulung dan kemudian ditimbun dengan "sanitary landfill".

\section{Klasifikasi Sampah Makanan}

Sampah makanan dapat diklasifikasikan menjadi 2 macam, berdasarkan waktu dan tingkat kemungkinannya. Berdasarkan waktunya, food waste dikategorikan menjadi 3 macam (Legrand, 2017):

a) Pre-consumer waste

Didefinisikan sebagai semua trimming, spoiled food, dan produk lain dalam kitchen yang akhirnya dibuang sebelum selesai diolah menjadi menu item yang akan dikonsumsi.

b) Post-consumer waste

Sampah yang tersisa pada saat konsumen telah mengkonsumsi makanan.

c) Packaging waste and operation supplies

Terutama dalam bentuk plastik yang tidak dapat terdekomposi dengan alami. Operating supplies merupakan semua bahan yang digunakan dan menjadi waste dalam operasi food service, seperti minyak goreng dan lampu.

\section{Pasar}

Menurut Peraturan Presiden Republik Indonesia Nomor 112 Tahun 2007, pasar secara umum dapat diartikan sebagai area tempat jual beli barang dengan jumlah penjual lebih dari satu baik yang disebut sebagai pusat perbelanjaan, pasar tradisional, pertokoan, mall, plaza, pusat 
perdagangan maupun sebutan lainnya. Pasar juga sebuah tempat atau proses interaksi antara pembeli dan penjual dari produk tertentu, sehingga dapat terjadinya harga ekuilibrium dan kuantitas. Terdapat 2 tipe pasar yaitu pasar tradisional dan swalayan (Sutami, 2012).

\section{Pasar Tradisional}

Pasar Tradisional merupakan sebuah tempat dimana adanya interaksi jualbeli antara pedagang dengan pengunjung secara langsung. Biasanya juga terdapat interaksi antara orang yang memproduksi suatu barang dengan orang yang hendak membeli barang tersebut (Sadilah, dkk, 2011).

\section{Sampah Makanan dalam Pasar}

Sampah kota di Indonesia mengandung $55-60 \%$ bahan organik. Di TPA sampah kota masih dipilah secara manual dan kemudian ditimbun dengan sanitary landfill (Mulyadi, 2019). Di negara berkembang seperti Indonesia, food waste Sebagian besar terjadi pada proses panen, distribusi, dan pengolahan, sebelum pangan sampai ke konsumen (pre-costumer waste). Sektor pangan lain yang banyak menghasilkan makanan adalah rumah makan (post-costumer waste).

\section{Sistem Pemasaran Pangan ke Pasar}

Sistem pemasaran pangan adalah aktivitas yang berkaitan dengan penyaluran makanan dari proses panen sampai ke konsumen. Kegiatannya antara lain pengolahan, grosir, eceran, servis, transportasi, dan lain-lain.

Sistem pemasaran melakukan layanan yang diperlukan untuk menyalurkann makanan dari produsen ke konsumen. Sebagian besar produk diproses, dikemas, disimpan, dan diangkut melalui sarana pemasaran sebelum sampai ke pasar. Besar dan jenis operasi ini bergantung pada sifat produk dan lokasi terhadap konsumen.

Dalam proses tersebut sebagian besar bahan pangan terbuang menjadi sampah makanan (food loss). Sistem pangan seperti inilah yang terjadi pada kota-kota besar sehingga banyak makanan yang terbuang sebelum sampai ke konsumen, oleh karena itu penting untuk memikirkan kembali cara untuk memanfaatkan sampah makanan tersebut.

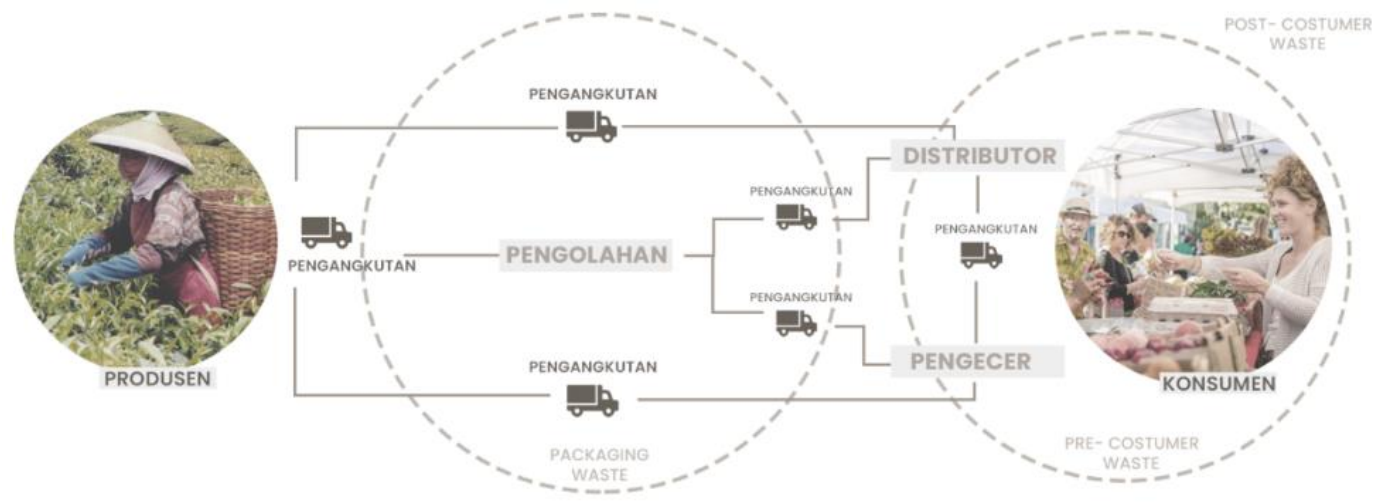

Gambar 1. Sistem Penyaluran Makanan ke Pasar Sumber: U S Department of Agriculture (dikelola Penulis) 


\section{Sistem Pemasaran Pangan yang Dikelola dari Food Waste}

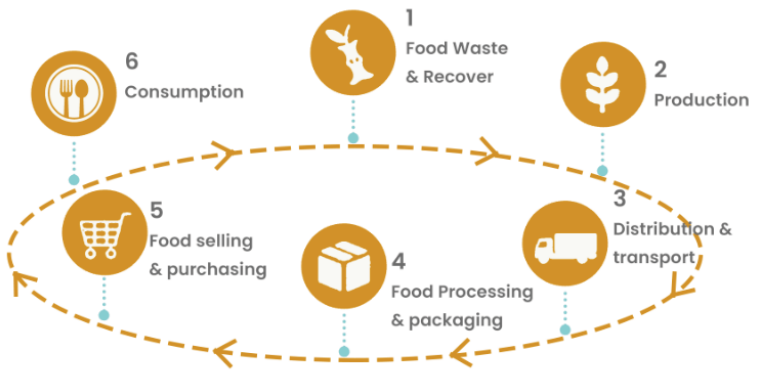

Gambar 2. Sistem Penyaluran Pangan yang didasari Food Waste Sumber: www.creativefoodcycles.org (dikekola Penulis)

Pada sistem siklus penyaluran bahan pangan ini, ada aktivitas yang dilakukan oleh Creative Food Cycle (CFC) yaitu gerakan dalam mengurangi sampah makanan. Cara yang dilakukan antara lain penggunaan bahan baku dengan limbah untuk menghasilkan makanan dan, untuk didistribusikan dan dikonsumsi, untuk memanfaatkan surplus makanan, hingga proses pengemasan menggunakan kembali dari bahan pangan itu sendiri.

\section{METODE}

\section{Tahap Perancangan}

Pada tahap penelitian, dimulai dari pemilihan isu yang diangkat berupa sampah makanan, kemudian pemilihan tapak yang relevan terhadap isu yang diangkat, mengidentifikasikan permasalahan dan potensi yang terdapat dalam tapak, mengusulkan program ke tapak dengan memperhatikan konteks sekitar tapak dan membagi zoning dalam tapak dan yang terakhir dari hasil perancangan.

\section{Metode Perancangan}

Proyek ini menerapkan metode sistem pengolahan sampah yang tertutup melalui sistem daur ulang sampah dalam program program arsitektur, sehingga menjadikan pasar tradisional menjadi pasar hijau bebas sampah makanan.

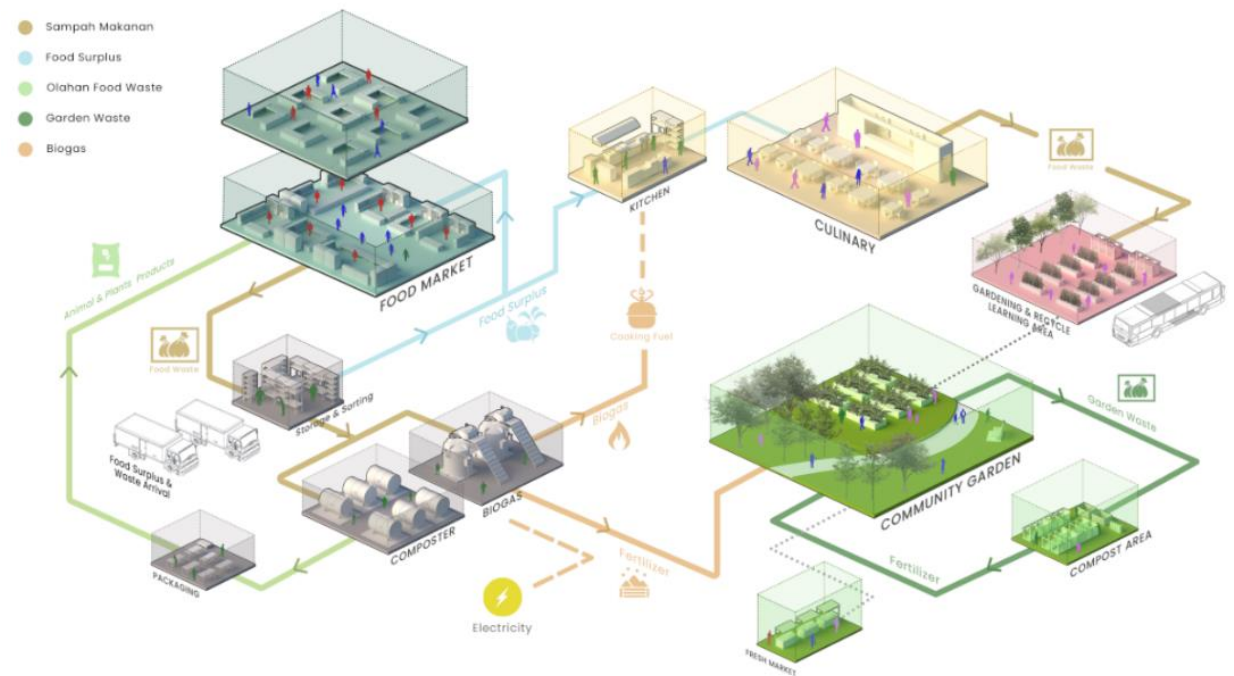

Gambar 3. Siklus Pengolahan Sampah Makanan

Sumber: Dokumentasi Penulis, 2021 


\section{DISKUSI DAN HASIL}
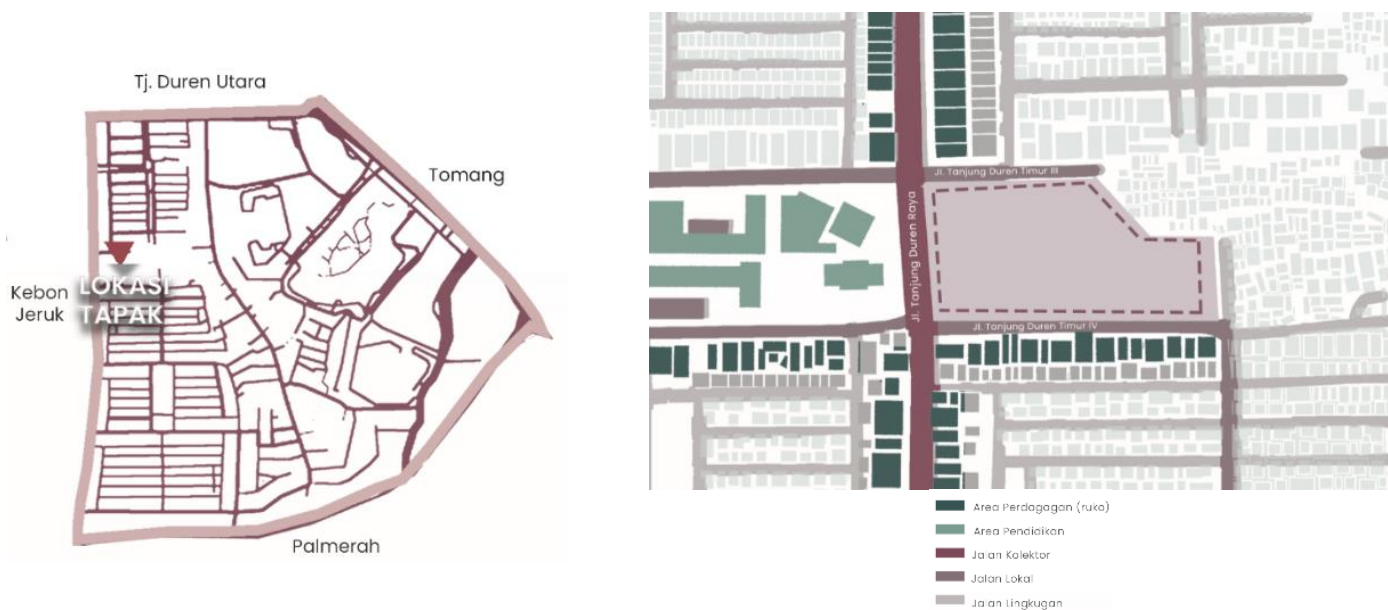

Gambar 4. Lokasi Tapak

Sumber: Google Maps (dikelola penulis), 2021

Lokasi proyek mengambil tapak Pasar Kopro dan mengambil lingkungan di sekitarnya. Dengan Zona K1 (zona Perkantoran, Perdagangan, dan Jasa) dan zona C1 (sub zona campuran). Pemilihan tapak pada Pasar eksisiting yaitu Pasar kopro dengan tujuan untuk menciptkan suatu sistem dalam pasar yang bebas sampah makanan, serta menciptakan lingkungan pasar yang lebih bersih.

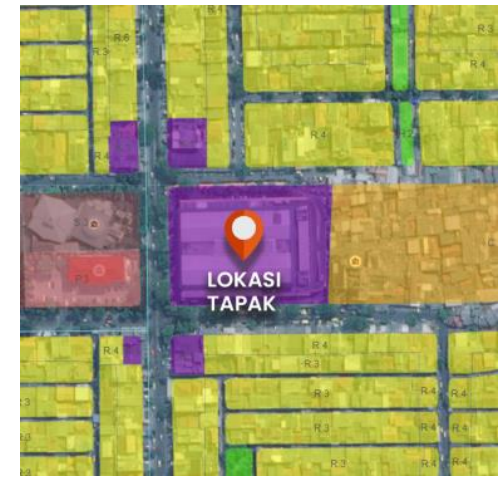

Gambar 5. Zonasi Tapak Proyek Terpilih

Sumber: Jakartasatu.com (dikelola penulis), 2021

Informasi Tapak

Alamat Ps. Jaya Tomang Barat, Jl. Tanjung Duren Raya No.14, RT.14/RW.5, Tj. Duren Sel., Kec. Grogol petamburan, Kota Jakarta Barat, Daerah Khusus Ibukota Jakarta 11470

Luas $\quad \pm 14.400 \mathrm{~m}^{2}$

Tapak

KDB $\quad 60\left( \pm 8.640 \mathrm{~m}^{2}\right)$

KLB $\quad 2,4\left( \pm 34.560 \mathrm{~m}^{2}\right)$

KDH $\quad 30\left( \pm 4.320 \mathrm{~m}^{2}\right)$

KB 4

KTB $\quad 55$

Pasar di Kawasan Grogol termasuk pasar kopro direncakan untuk direvitalisasi pada tahun 2018 
oleh Gubernnur Jakarta. Revitalisasi pasar yang ada di Pasar Kopro bertujuan untuk membangun kembali pasar yang sudah ada menjadi lebih rapih dan bebas kemacetan. Konsep pasar yang akan dibangun didampinngi oleh hunian (rusunami), sehingga dapat menigkatkan transaksi jual beli antara penghuni dengan pasar, dan mengurangi kemacetan (Anata, 2018).

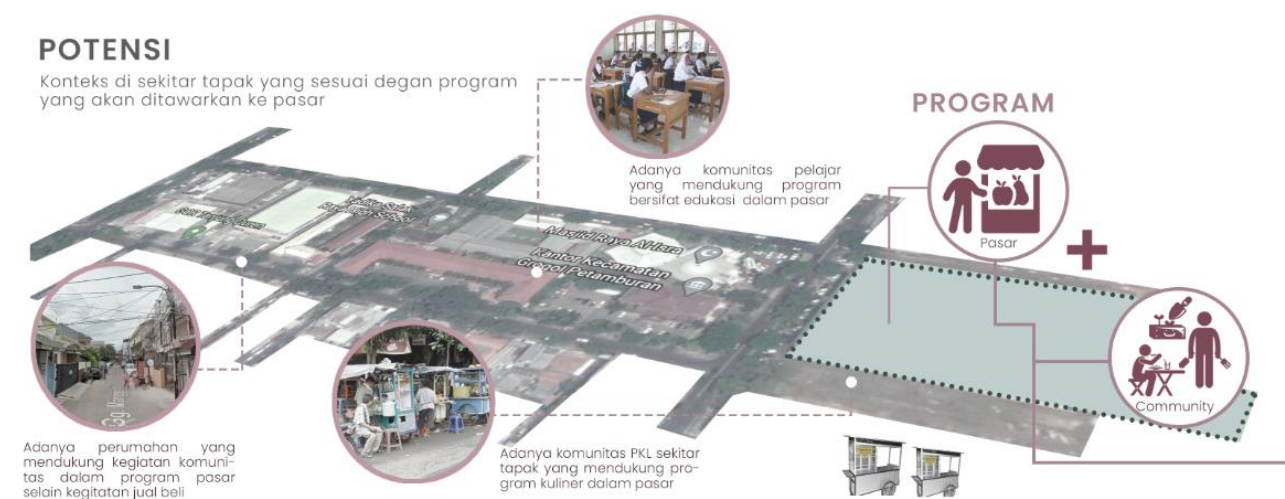

Gambar 6. Analisis Penulis

Sumber: Dokumentasi pribadi, 2021

Depan lokasi tapak ini sering terjadi kemacetan hampir setiap jarnnya, disebabkan oleh aktifitas pasar pada pagi harinya, jam makan siang kantor, jalur pulang kerja pada sore harinya, serta tempat makan pada malam harinya, kemacetan lainnya juga disebabkan oleh banyaknya kendaran umum yang berhenti untuk mencari penumpang seperti bus 91 , dan bajaj serta ojek yang parkir di depan trotoar/pinggir jalan.
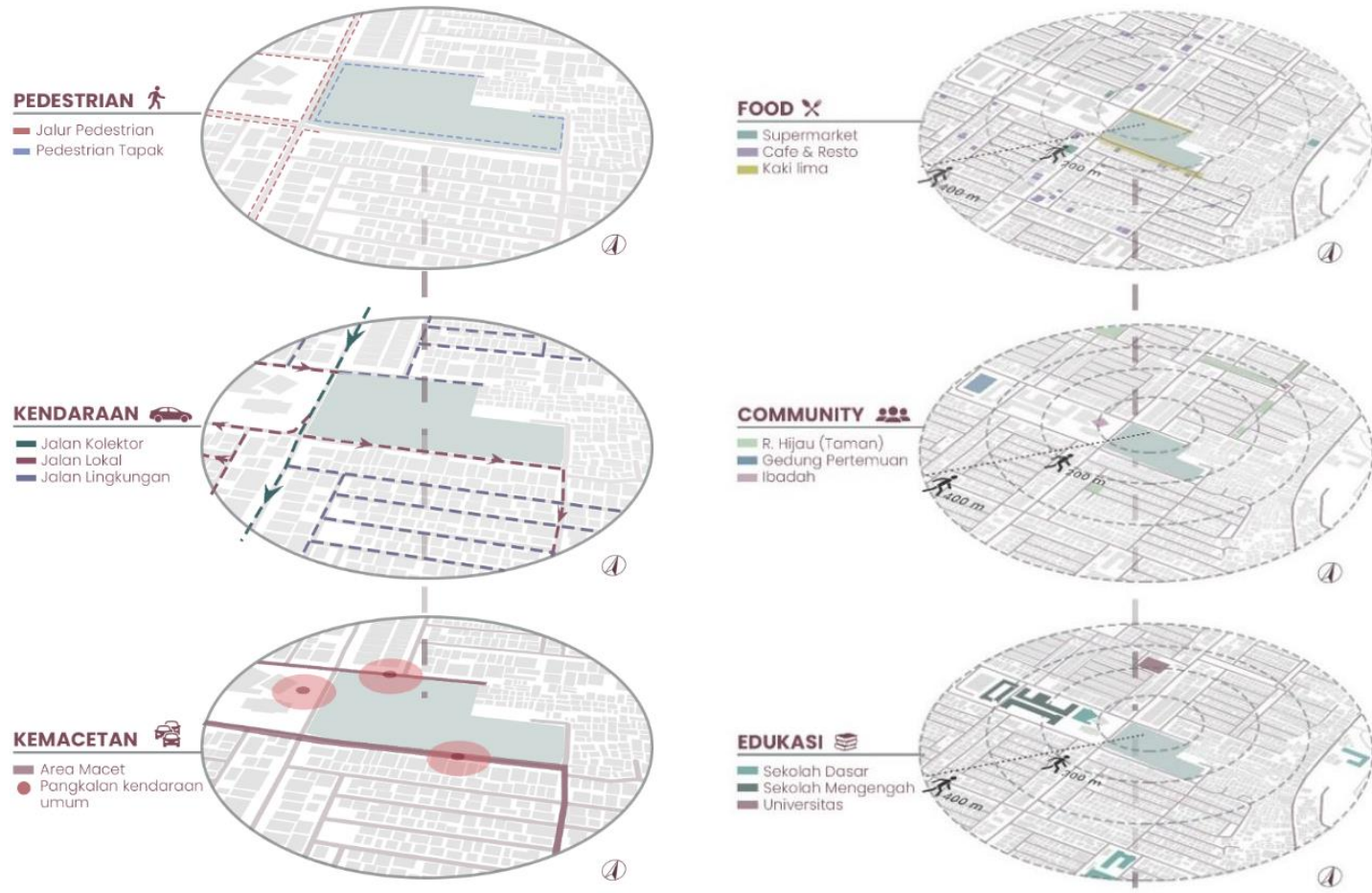

Gambar 7. Analisis Penulis

Sumber: Dokumentasi pribadi, 2021

Selanjutnya, penentuan gubahan massa didasarkan dengan konteks sekitar tapak dengan zoning dan program ditentukan lokasinya yang sesuai dengan tapak sekitarnya. 


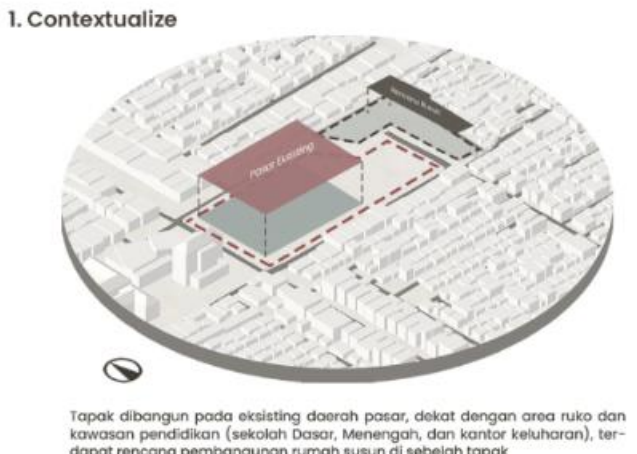
kawasan pendidikan (sekolah Dasar, Menengah, dan kantor keluharan), ter-

3. Flow Pengunjung

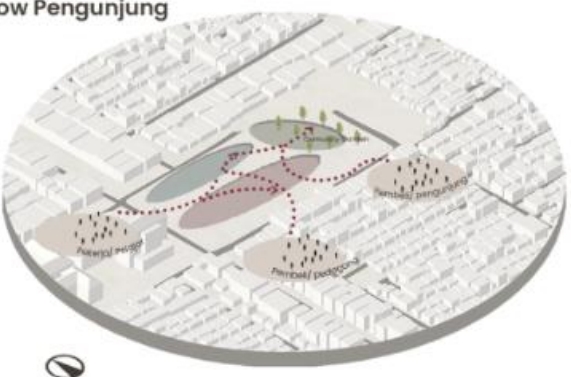

Mengkoneksi pengunjung ke dalarn ketiga porgram di pasar. Pengjunjung
dikelompokkan dalam 2 , yaitu pengunjung pasar dan area komersial (Culinary

5. Cross / Cut

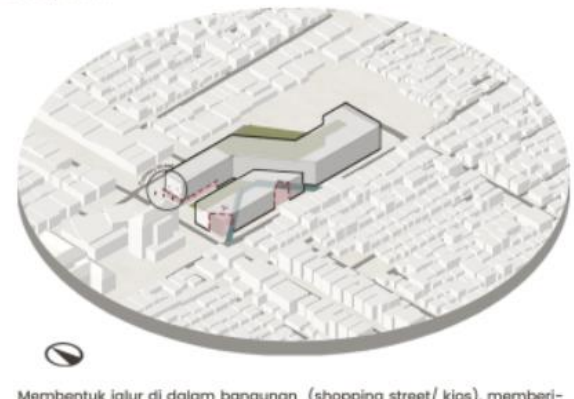

kan space untuk penjual (PKL) di dalam tapak dan ruang untuk pejalan

7. Ramp \& Connection

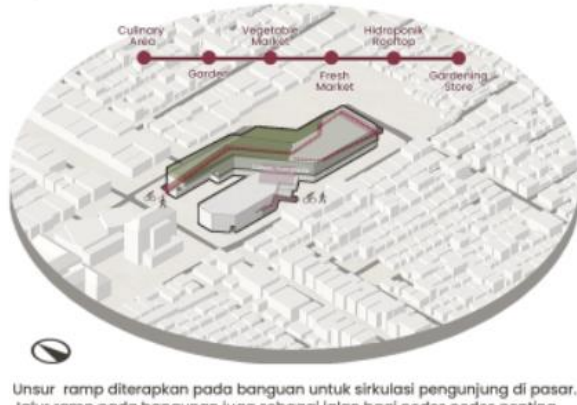

Unsur ramp diterapkan pada banguan untuk sirkulasi pengunjung di pasar.
Jalur ramp pada bangunan juga sebogai jalan bogi nodes nodes penting.

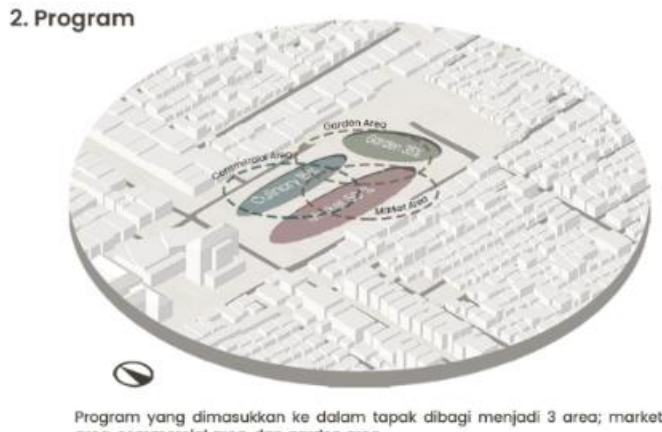

Program yang dimasukkan ke dalam topat

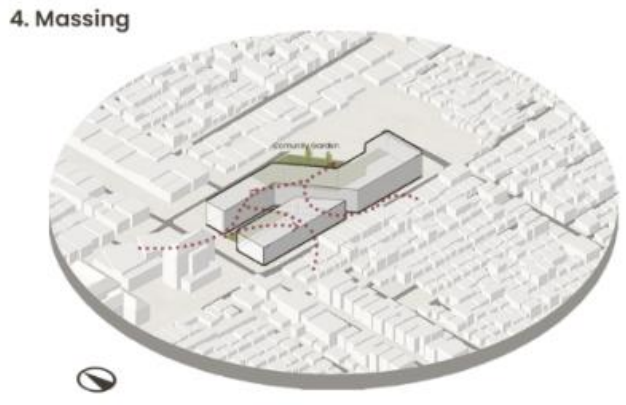

Peletakan massa awal berdasarkan target pengunjung pada lingkungan, tertapak

6. Garden Area

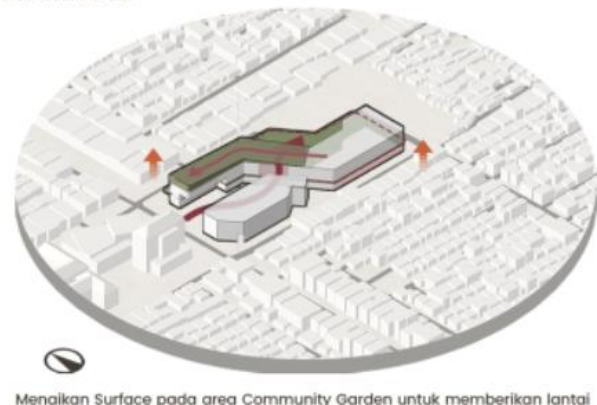

dasar space untuk sirkulasi dan parkir kendaraan.

8. Sirkulasi

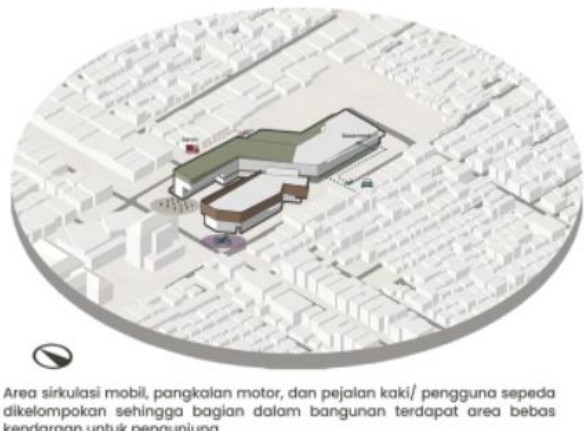

Gambar 8. Diagram Proses Gubahan Massa

Sumber: Dokumentasi pribadi, 2021

Setelah proses gubahan massa, proses selanjutnya adalah menentukan pembagian ruang dalam pasar per lantainya secara mendetail dalam rancangan serta membagi ruang dalam luasan yang sudah ditentukan. Pasar hijau tradisional ini memiliki sistem yang bekerja berupa siklus 
pengolahan sampah yang tertutup, sampah makanan diolah dan hasilnya dapat digunakan untuk kebutuhan program lain di pasar, sehingga sirkulasi dan networking antar pasar menjadi hal yang penting dalam dalam desainnya berupa penggunaan ramp yang menjadi jalur utama penghubung antar program yang dipasang mengelilingi bangunan.

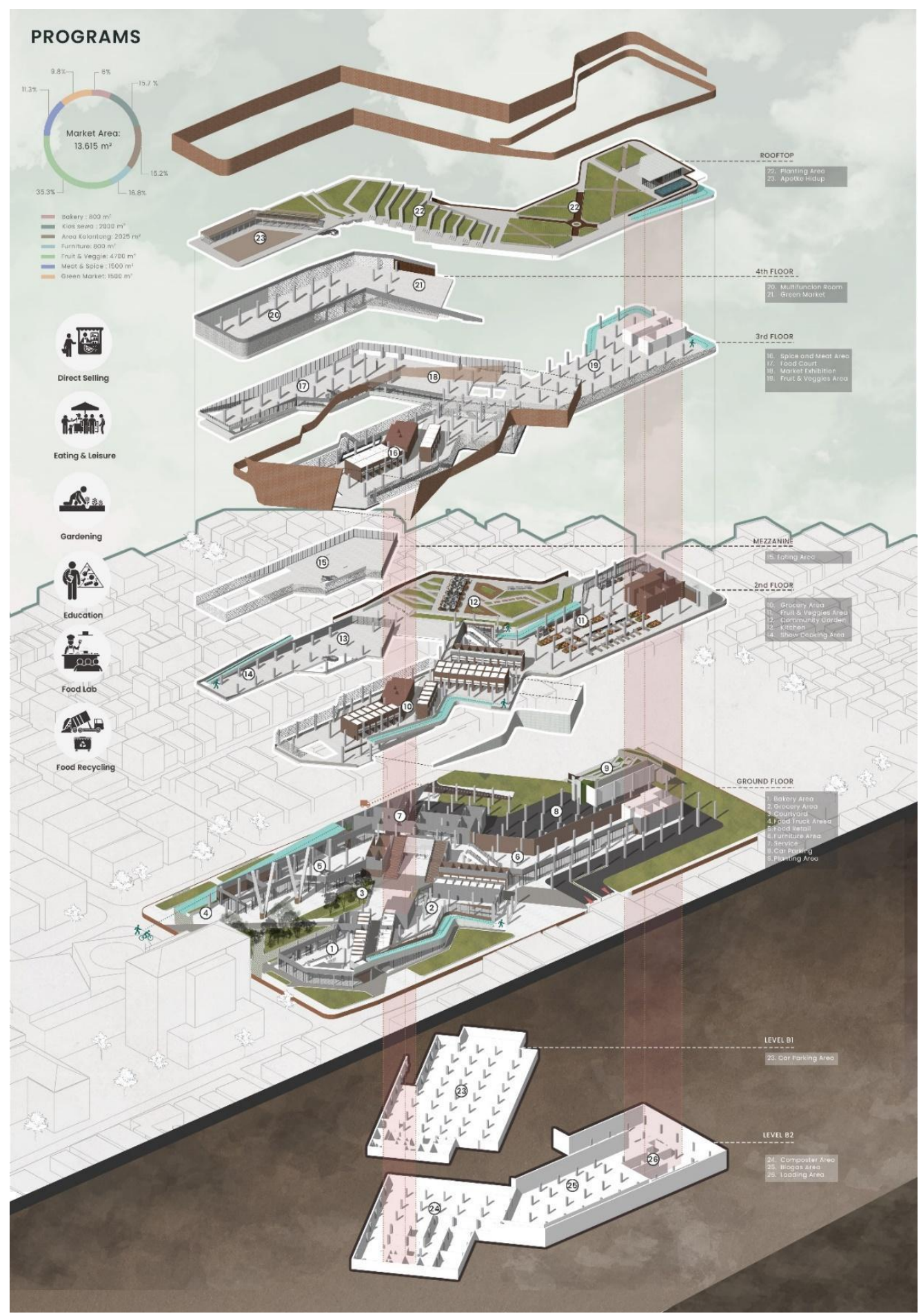

Gambar 9. Pembagian Program dalam Pasar

Sumber: Dokumentasi penulis, 2021 


\section{KESIMPULAN DAN SARAN \\ Kesimpulan}

Proyek ini dirancang sebagai sarana untuk memanfaatkan kembali sampah makanan sebagai bahan baku yang dapat dikomersialkan. Pemanfaatan sampah-sampah makanan didapat dari sektor-sektor yang menghasilkan banyak sampah makanan, oleh karena itu tempat yang sesuai adalah daerah yang terdapat banyak sektor pangan. Melalui pemanfaatan sampah makanan maka akan mengurangi dampak yang ditimbulkan oleh sampah makanan ke lingkungan, serta memperoleh manfaat bagi sektor pangan, peternakan, dan pertanian dari pengolahan sampah makanan tersebut. Untuk itu, proyek ini berusaha menerapkan sistem pengolahan sampah ke dalam arsitektur pasar tradisional sehingga menjadi pasar hijau bebas sampah makanan.

\section{Saran}

Dalam menerapakan arsitektur hijau yang pada pasar tradisional sebaiknya memperhatikan lingkungan sekitar supaya dapat mengimplementasikan desain yang sesuai dengan konteks lingkungan. Sirkulasi dan networking adalah poin penting di dalam pasar sehingga desain pembagian program dan hubungan antar ruang didasarkan oleh networking dalam pasar. Dengan hadirnya proyek ini, diharapkan dapat menjadi salah satu jawaban permasalahan ekologi berupa sampah makanan.

\section{REFERENSI}

Ananta, Y. (2018, April 18). Tiga Pasar Jadi Lokasi Percontohan Rusun DP RpO. Retrieved from Media Indonesia: https://mediaindonesia.com/megapolitan/157299/tiga-pasar-jadilokasi-percontohan-rusun-dp-rp0

Darby H., Natural Resources Defense Council. (2017). Estimating Quantities and Types of Food Waste at the City Level. New York: Natural Resources Defense Council.

Dewi, R. (2020, Januari 17). Bom Waktu Itu Bernama Sampah Makanan. Retrieved from Kumparan: https://kumparan.com/kumparannews/bom-waktu-itu-bernama-sampahmakanan-1sey9ZZUcFw

FAO. (2011). Global Food Losses and Food Waste. Rome: FAO.

FAO. (2016, April 12). Key facts on food loss and waste you should know! Retrieved from twosides.info: https://twosides.info/includes/files/upload/files/UK/Myths_and_Facts_2016_Sources/ 18-19/Key_facts_on_food_loss_and_waste_you_should_know-FAO_2016.pdf

Garfield, L. (2017, Oktober 16). A third of the planet's food goes to waste - here's what we throw out the most. Retrieved from Business Insider: https://www.businessinsider.com/food-world-wastes-most-2016-10?r=US\&IR=T

Gausa, M. N., Pericu, S., Canessa, N., \& Tucci, G. (2020). Creative Food Cycles: A Cultural Approach to the Food Life-Cycles in Cities. Department Architecture and Design (DAD), Università di Genova.

Jann, M. L. (2016). Secondhand, the City's antidote for food surplus. Department of Architecture, University of strathclyde Engineering.

Legrand, W., Sloan, P., \& Chen, J. S. (2017). Sustaiability in the hospitality industry (3rd ed.). . London: Routledge.

Linstrom, H.R. (1978). Farmer to Costumer Marketing . U.S. Department of Agriculture, Economics, Statistic, and Cooperatives Service.

Mulyadi, S. (2019). SAMPAH MAKANAN atau FOOD WASTE. PT. Amrita Enviro Energi Newsletter 33/ VI, 1-3.

Siaputra, H., Chrisiani, N., \& Amanda, G. (2019). Analisa Implementasi Food Waste Management di Restoran ' $X$ '. Program Manajemen Perhotelan, Program Studi 
Manajemen, Fakultas Ekonomi, Universitas Kristen Petra Jurnal Manajemen Perhotelan Vol. 5, NO. 1, 1-8.

Sistem Informasi Pengelolaan Sampah Nasional. (2020). Komposisi Sampah. Retrieved from sipsn.menlhk.go.id: http://sipsn.menlhk.go.id/sipsn/public/data/komposisi

Stuart, T. (2009). Waste - uncovering the global food scandal. London: Penguin Books. doi:ISBN: 978-0-141-03634-2

Tentang Perpasaran, No. 2 (Peraturan Daerah Provinsi Daerah Khusus Ibukota Jakarta 2018). The Inteligence Unit. (2016, September). Food loss and food waste. Retrieved from perspectives.eiu: http://perspectives.eiu.com/sustainability/foodsustainability-index2016/infographic/food-lossand-waste 